\title{
Diversity of aphid pests on the crops in Kanchanpur district, Nepal
}

\author{
Mahadev Bista ${ }^{1}$ \\ ${ }^{1}$ Department of Zoology, Siddhanath Science Campus, \\ Tribhuvan University, Mahendranagar, Nepal \\ bistamahadev@yahoo.com
}

\begin{abstract}
A survey was conducted to explore the aphid pests' diversity in Kanchanpur district, far-western, Nepal from April 2018 to March 2019. A total of 15 aphid pests were collected and identified, viz. Acyrthosiphon pisum (Harris), Aphis craccivora (Koch), Aphis gossypii (Glover), Aphis fabae (Scopoli), Aphis nerii Boyer de Fonscolombe, Brevicoryne brassicae (Linnaeus), Lipaphis erysmi (Kaltenbach), Macrosiphum euphorbiae (Thomas), Macrosiphum rosae (Linnaeus), Myzus persicae (Sulzer), Rhopalosiphum maidis (Fitch), Rhopalosiphum padi (Linnaeus), Rhopalosiphum rufiadominale (Sasaki), Uroleucon compositae (Theobald), and the guava aphid. Exploration of aphid pests showed that they caused serious damages to agricultural crops by attacking different parts of plants.
\end{abstract}

Keywords: aphids, host plants, baseline data, far-western region, control

\section{INTRODUCTION}

Aphids (Hemiptera: Aphididae) are among the most destructive and widely distributed herbivorous insect pests. They suck up plant sap, hamper plant growth and spread several plant virus diseases, thereby causing the loss of output in agriculture, horticulture, floriculture, silviculture and forestry sectors. Worldwide, more than 7,757 aphid species have been recognized so far (Misra \& Kurl, 1979). The aphids are polyphagous in nature, have intricate life cycles, telescopic generations and show close associations with their host plants (Dixon, 1998). They are highly polyphenic and have the ability to reproduce both sexually and asexually. Their increased numbers on the host plant are known to stunt the plant growth; deform and discolour the leaves and fruits; cause formation of galls on leaves, stems and roots (Hamman, 1985); and act as vectors of many viral diseases (Hull, 1981; de Zoeten \& Skaf, 2001; Katis et al.., 2006). Owing to their immense damaging capabilities there is a severe need for 
opting the effective management strategies and bringing down their numbers below the economic injury levels.

Majority of the plants have one or more species of aphids that are known to feed on them. Through their huge reproductive ability, the aphids can cause severe damages to crops. The management of aphids includes various strategies, such as physical, mechanical, hormonal, anti-hormonal, pheromonal and microbial control methods. However, the use of synthetic pesticides (chemical control) and the employment of natural enemies (biological control) are the popular ones. Presently, most of the aphid control programs are based on the use of chemical insecticides. But continuous usage of chemicals has several disadvantages, like pest resistance, environmental contaminations, and sometimes the outbreak of secondary pests (Luckman \& Metcalf, 1978; Onstad, 2008; Whalon et al., 2008]. Several aphid species have developed resistance to at least seventy different synthetic compounds (Edwards and Lawrence, 2006; Silva et al., 2012), and such entomological backlashes have bound the scientists to be concerned with the environment-friendly pest management programs.

Management of pests requires an understanding of the ecology of the cropping system, including that of the pests, their natural enemies, and the surrounding environment. Timely monitoring of pest populations gives information needed to decide if and when to apply a specific control measure for optimal effectiveness. There are scarcities of research on aphid management in environmentally safer manner, more specifically using seasonal information and the natural enemies in Nepal. While, the aphid fauna of Nepal is rich and diverse, but it is poorly studied as compared to those from other zoogeographical regions of the world (Sharma, 2000; Thapa, 2015). In addition, the knowledge and understanding of the diversity and abundance of aphids will help in identifying the suitable control practices. Thus, the present study was aimed to explore the aphid diversity of Kanachanpur district, Nepal leading to pave the way towards future exploration of aphid pests from other parts of Nepal.

\section{Study area}

Present study was carried out in Kanchanpur district situated at $28^{\circ} 32^{\prime}$ to $29^{\circ} 08^{\prime} \mathrm{N}$ latitudes, and $80^{\circ} 03^{\prime}$ to $80^{\circ} 33^{\prime} \mathrm{E}$ longitudes. The study area shows three distinct seasons, viz. winter, summer and monsoon. Winter season continues from November 
to February, where days are moderate and nights are very cold. The summer season is from March to June, with a maximum temperature up to $44^{\circ} \mathrm{C}$ during the day. The monsoon season starts from July and continues up to September. The collection of adult aphids was carried out from four different parts, viz. Bhimdatnagar, Beldadi, Krishnapur and Punrbas of Kanchanpur district. Samples of specimens were preserved from April 2018 to March 2019.

\section{MATERIALS AND METHODS}

\section{Collection and identification of aphid species}

Aphids were collected from their host plants in Beldadi, Krishnapur and Punrbas of Kanchanpur district, using soft camel hair brush and preserved into a small vials containing $70 \%$ ethanol for further identification in the laboratory of Zoology, Siddhanath Science Campus, Mahendranagar. Aphids were identified under the Olympus binocular microscope (provided with oculometer) at $10 \times 40$ magnification using the keys suggested by Blackman \& Eastop (1994, 2000, 2012). The key morphological characters were used for diagnostic description referring to Blackman \& Eastop (1994, 2012), and for the morphometric analysis of the studied data. The photographs available from the previous literature were also used for visual identification.

\section{RESULTS AND DISCUSSION}

Fifteen species of aphids were reported from the five different sites (table 1) among the total of 120 samples collected from the various study sites (Beldadi, Krishnapur and Punrbas) of Kanchanpur district, far-western region, Nepal. They were collected from different crop plants, like Rice (Oryza sativa), Wheat (Triticum aestivum), Maize (Zea mays), Cotton (Gossipium arboretum), Pea (Pisum sativum), Cowpea (Vigna unguiculata), Mustard (Brassica campestris), Kalo Maas (Phaseolus mungo), the vegetables plants, viz. Chili (Capsicum frutescens), Brinjal (Solanum melogena), Potato (Solanum tuberosum), Cabbage (Brassica oleracea), the ornamental plants, like Rose (Rosa indica), Godawari (Chrysanthemum spp.), the horticulture plants, like Guava (psidium guagava), and the forest plants like Aankh (Calotropis gigantea). 
98 Bista: Diversity of aphid pests on the crops in Kanchanpur district, Nepal

Table 1. List of aphid species, their host plants and the infested parts.

\begin{tabular}{|c|c|c|c|}
\hline S.N. & Aphid species & Host plant & Infested parts \\
\hline 1. & Acyrthosiphon pisum (Harris) & Pisum sativum & Stems \\
\hline 2. & Aphis craccivora (Koch) & Vigna unguiculata & $\begin{array}{c}\text { Fruits, flowers and } \\
\text { leaves }\end{array}$ \\
\hline 3. & Aphis gossypii (Glover) & $\begin{array}{l}\text { Gossipium } \\
\text { arboretum, } \\
\text { Capsicum } \\
\text { frutescens }\end{array}$ & Stems and leaves \\
\hline 4. & Aphis fabae (Scopoli) & Phaseolus mungo & $\begin{array}{c}\text { Fruits, buds and } \\
\text { leaves }\end{array}$ \\
\hline 5. & $\begin{array}{l}\text { Aphis nerii Boyer de } \\
\text { Fonscolombe }\end{array}$ & $\begin{array}{l}\text { Calotropis } \\
\text { gigantean }\end{array}$ & $\begin{array}{l}\text { Leaves, buds and } \\
\text { Fruits }\end{array}$ \\
\hline 6. & $\begin{array}{l}\text { Brevicoryne brassicae } \\
\text { (Linnaeus) }\end{array}$ & Brassica oleracea & Leaves and flowers \\
\hline 7. & Lipaphis erysmi (Kaltenbach) & $\begin{array}{l}\text { Brassica } \\
\text { campestris }\end{array}$ & $\begin{array}{c}\text { Flowers, leaves, } \\
\text { buds, fruits and stems }\end{array}$ \\
\hline 8. & $\begin{array}{l}\text { Macrosiphum euphorbiae } \\
\text { (Thomas) }\end{array}$ & $\begin{array}{l}\text { Solanum } \\
\text { tuberosum }\end{array}$ & Leaves and buds \\
\hline 9. & Macrosiphum rosae (Linnaeus) & Rosa indica & $\begin{array}{l}\text { Leaves, flowers and } \\
\text { buds }\end{array}$ \\
\hline 10. & Myzus persicae (sulzer) & $\begin{array}{l}\text { Solanum } \\
\text { melogena }\end{array}$ & Leaves \\
\hline 11. & Rhopalosiphum maidis (Fitch) & Zea mays & $\begin{array}{c}\text { Steam, buds and } \\
\text { leaves }\end{array}$ \\
\hline 12. & $\begin{array}{l}\text { Rhopalosiphum padi } \\
\text { (Linnaeus) }\end{array}$ & Triticum aestivum & $\begin{array}{l}\text { Leaves, stems and } \\
\text { fruits }\end{array}$ \\
\hline 13. & $\begin{array}{l}\text { Rhopalosiphum rufiadominale } \\
\text { (Sasaki) }\end{array}$ & Oryza sativa & $\begin{array}{l}\text { Leaves, stems and } \\
\text { roots }\end{array}$ \\
\hline 14. & Uroleucon compositae & $\begin{array}{l}\text { Chrysanthemum } \\
\text { spp. }\end{array}$ & Steams and leaves \\
\hline 15 . & Guava Aphid & Psidium guagava & Leaves and buds \\
\hline
\end{tabular}

\section{Acyrthosiphon pisum (Harris, 1776)}

Acyrthosiphon pisum is commony known as the pea aphid. The body length of $A$. pisum apterae ranges from 2.2 to $5.0 \mathrm{~mm}$ long, pale green or pink with red eyes and the antennae are 1.0-1.6 times as long as the body. The alate viviparous female has 
the head and thorax only slightly darker than the abdomen which is pale with small marginal sclerites. The adult female lays fertilized eggs that overwinter in autumn and the eggs get hatched in spring producing nymphs which are all females and undergo four moults before reaching the sexual maturity. It feeds on several species of legumes worldwide, such as pea, clover, alfaalfa, and broadbean (fig.1).

\section{Aphis craccivora (Koch, 1854)}

Aphis craccivora is abundant in the Mediterranean areas and the subtropical and tropical regions. It is also known as the 'cowpea aphid' or 'black bean aphid'. The winged females are up to $2.2 \mathrm{~mm}$ long, but the wingless females are a little smaller. The female has a glossy black or dark brown body with a prominent cauda, antennae six segmented, legs in shades of brown or yellow, and the cornicles are pale proximally but dark distally. The adults do not have wax on their dorsal surface but the nymphs are lightly dusted with wax. The eggs of $A$. craccivora hatch in early spring to produce all females that reproduce by parthenogenesis, producing nymphs which moult four times over the course of 8-12 days. The aphid is polyphagous and feeds on a large number of different plant species (fig. 1).

\section{Aphis fabae (Scopoli, 1763)}

Aphis fabae or the 'black bean aphid' is the most widely distributed species throughout the temperate region. The aphid is usually seen in large numbers and is a tiny, about $2 \mathrm{~mm}$ long with small head, bulbous abdomen and the body is blackish or dark green in colour. It is able to reproduce asexually, giving birth to nymphs through parthenogenesis. The aphid is a major pest of sugerbeet, beans, potatoes, sunflowers, tobacco and tomatoes (fig.1).
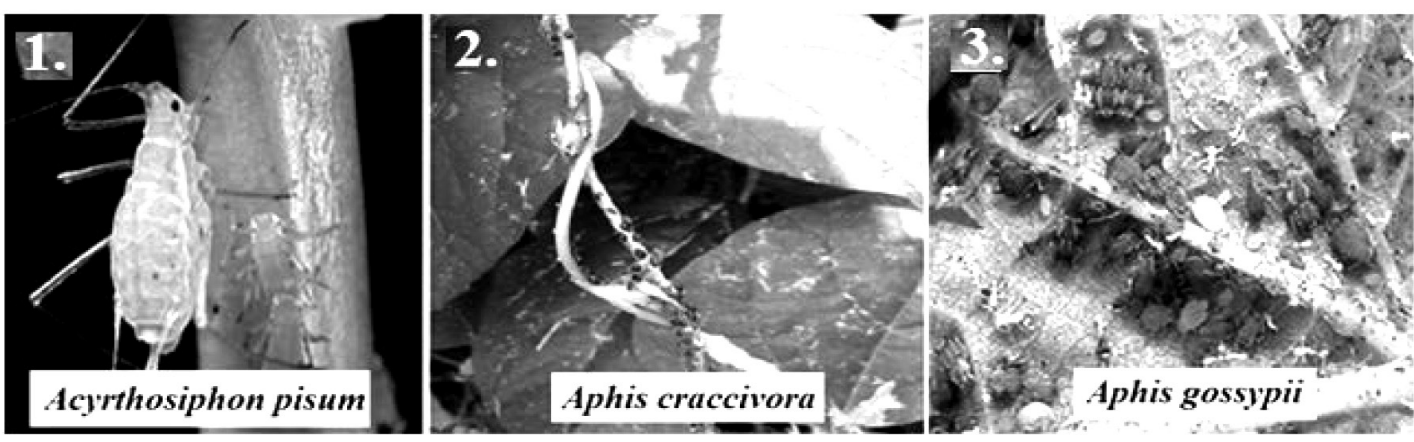
Fig. 1. Aphid species: (1.) Acyrthosiphon pisum, (2.) Aphis craccivora, (3.) Aphis gossypii.

\section{Aphis gossypii (Glover, 1877)}

It is cosmopolitan in habitat but mostly found in tropical and temperate regions throughout the world. Aphis gossypii is a tiny, small succulent, pear-shaped hemipteran insect, having an ovoid body which is about $2 \mathrm{~mm}$ long. The head and thorax of alate females are black, while their lateral spots and the antennae are longer than those of apterous females. The legs are yellow, as are the antennae which are three quarters of the length of the body. The nymphs and adults of $A$. gossypii suck the sap from tender shoots, stems and leaves. Both winged and wingless forms breed parthenogenetically to produce nymphs that vary in colour, having shades of green, tan and gray; and the body appears dull because it is dusted with wax secretions. The aphid is widely distributed pest of a variety of agricultural crops of families Cucurbitaceae, Rutaceae and Malvaceae (fig.2).

\section{Aphis nerii Boyer de Fonscolombe, 1841}

It is found in many countries especially the tropical and subtropical regions. It is lemon-yellow in colour and its life stages have dusky to black siphunculi, legs and antennae. The body of adult aphid is about 1.5-2.6 $\mathrm{mm}$ long and has a black cauda. Female aphids produce nymphs through viviparity that reproduce by parthenogenesis. The aphid is mainly found on plants of family Apocynaceae, but sometimes is also found on plants of other families (fig.2).

\section{Brevicoryne brassicae (Linnaeus, 1758)}

Brevicoryne brassicae or the 'cabbage aphid' is native to Europe, but now has a worldwide distribution. The aphid is a key pest of various cruciferous crops, like cabbage, cauliflower, kale and other such Brassicae species. It is 2.0 to $2.6 \mathrm{~mm}$ long and covered with grayish waxy covering. The cabbage aphid is difficult to distinguish from the turnip aphid (Lipaphis erysmi (Kaltenbach). This aphid feeds in colonies of large numbers on young leaves, mostly on the undersurface and also on tender parts and causes considerable damage (fig.2). 

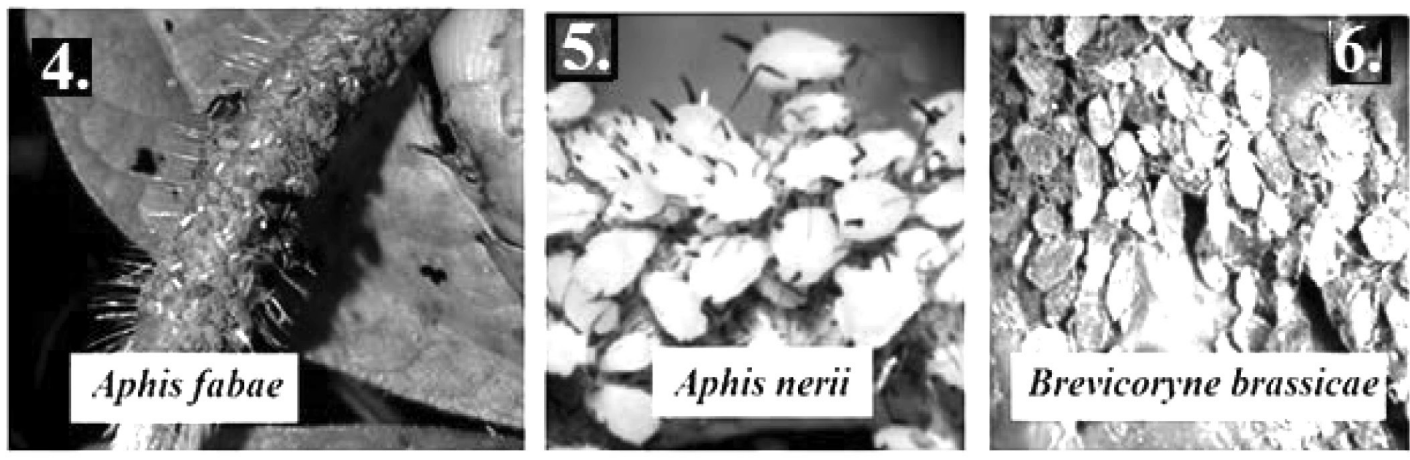

FIg. 2. Aphid species: (4.) Aphis fabae, (5.) Aphis nerii, (6.) Brevicoryne brassicae.

\section{Lipaphis erysmi (Kaltenbach, 1843)}

Lipaphis erysmi is found mostly in temperate and tropical areas of the world. It is between 1.4 and $2.4 \mathrm{~mm}$ (0.06 and 0.09 in ) in length. The winged female has a black head, pale green thorax and black abdomen. Antennae and legs are dark. The wingless males are occasionally seen, being smaller than females and olive-green to brownish in colour. The aphid is almost entirly viviparous, although eggs have occasionally been seen. The host plants of L. erysmi include cabbage, cauliflower, broccoli, radish, turnip and other cruciferous plants (fig.3).

\section{Macrosiphum euphorbiae (Thomas, 1878)}

Macrosiphum euphorbiae originated in North America, but has spread to the temperate and tropical parts of the world. It has variable body colour, usually being either a shade of yellowish-green or the pinkish-red. Both aptere and alatae are medium to large in size, being 1.7-3.6 mm long. The antennae are dark at the joints between the segments and legs are longer than in other aphids, pale green but darker at the apices. The female produces upto seventy nymphs by parthenogenesis over the course of three to six weeks, and maybe ten generations over the summer. Macrosiphum euphorbiae is highly polyphagous on secondary hosts, especially potato and tomato. It is also common on sweet potato, roses, lettuce, maize and many other cultivated plants (fig.3).

\section{Myzus persicae (sulzer, 1776)}

Myzus persicae is found throughout the world. It is known as the 'green peach aphid' because it is usually found on peach trees. Adults appear in summer, and are 
$1.8-2.1 \mathrm{~mm}$ long; the head and thorax are black, and the abdomen is yellow-green with a dark patch on the back. Myzus persicae feeds a wide variety of herbaceous plants, including vegetable crops and other crops of family solanaceae. It has the only viviparous summer stages that feed so widely; while the oviparous winter stages are much restrictive in their diet choice (fig.3).
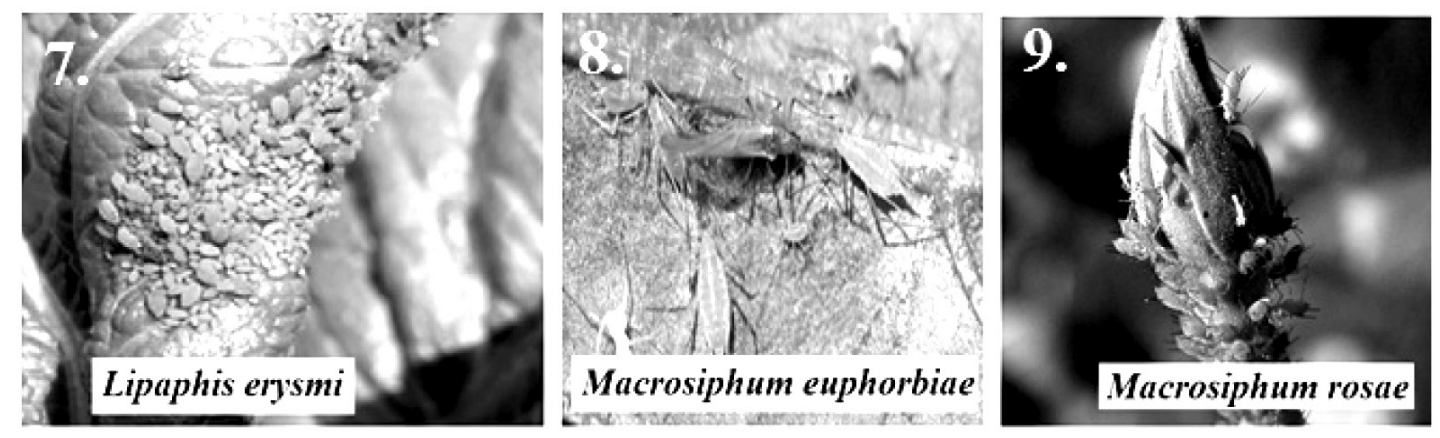

Fig. 3. Aphid species: (7.) Lipaphis erysimi, (8.) Macrosiphum euphorbiae, (9.) Macrosiphum rosae.

\section{Macrosiphum rosae (Linnaeus, 1758)}

Macrosiphum rosae or the 'rose aphid' is another species of sap-sucking insect of family Aphididae. Wingless adults have a spindle-shaped body and are between 1.7 and $3.1 \mathrm{~mm}$ long, slender, varying in colour from green to pink and reddish-brown. The antennae and legs are relatively long, and the cauda is pale. Winged forms develop when plants are heavily infested and aphids need to migrate to new host plants. It infests rose-bushes as its main host in spring and early summer, congregating on the tips of shoots and around the new buds. Rose is the primary host for this aphid (fig.4).

\section{Rhopalosiphum maidis (Fitch, 1856)}

Rhopalosiphum maidis is commonly known as 'corn leaf aphid'. It has worldwide distribution. The body length is about $2.0 \mathrm{~mm}$. The body of apterous $R$. maidis females is bluish-green in colour and the cauda are brown-black. However, the head, thorax, siphunculi, cauda and legs of alate females are black, but the abdomen is blue-green. The aphid sucks the sap from the whorled leaves during vegetative stage of the crop. It also feeds on the panicles and produces honeydew on which the sooty moulds grow. The aphid reproduces throughout the year by viviparous parthenogenesis. It is the major pest of maize and other host plants, like barley, green beans, papaya, rice, wheat and sugarcane (fig.4). 
Rhopalosiphum padi (Linnaeus, 1758)

Rhopalosiphum padi has a worldwide distribution. Its adults are $2 \mathrm{~mm}$ long, olivegreen to black in colour with a red rust patch at the rear end, and may have wings. Antennae extend to half the body length. It attacks all major cereals and pasture grasses, particularly barley, wheat, and oats. It can also be found on maize. It is a true bug and sucks sap from different plants directly on steams, leaves and heads. Life cycle includes production of many generations throughout the growing season. The nymphs are similar but smaller in size. Both winged and non winged forms occur (fig.4).
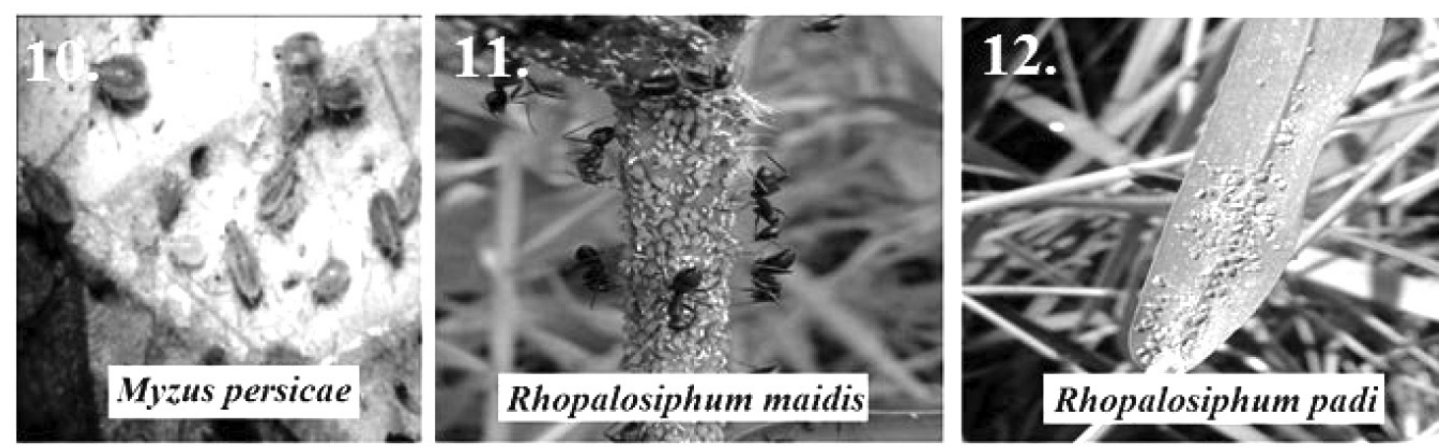

Fig. 4. Aphid species: (10.) Myzus persicae, (11.) Rhopalosiphum maidis, (12.) Rhopalosiphum padi.

\section{Rhopalosiphum rufiadominale (Sasaki, 1899)}

Rhopalosiphum rufiabdominale is nearly cosmopolitan in distribution, but of significant economic importance in warm-temperate, subtropical, and tropical climates. It has broad host range, having been recorded from species of over 22 plant families. It is principally a pest of upland rice but not that of lowland. The crops affected include oats, barley, millet, wheat, cotton, tobacco, potato, tomato and sugarcane. The pest feeds on the root, steam and leaves of the host plants. Its severe infestation within the roots causes the host plants to become discoloured and distorted, and eventually the plants die (fig.5).

\section{Uroleucon compositae (Theobald, 1915)}

Uroleucon compositae is found in temperate and tropical regions of the world. The aphid is medium-sized to large (2.1-4.1 mm), broadly spindle-shaped, very dark-red to almost black. It has black siphunculi, and the cauda and antenna are as long as the body. 
104 Bista: Diversity of aphid pests on the crops in Kanchanpur district, Nepal

The aphid makes dense colonies near flower stalks and damages the young shoots. It has a narrow host range feeding on many plant species of family Asteraceae (fig.5).

\section{Guava Aphid}

The host plant of guava aphid is Psidium guagava. The aphid infests the leaves and buds of the host plant. Its severe infestation eventually causes the plant to die (Figure 5).

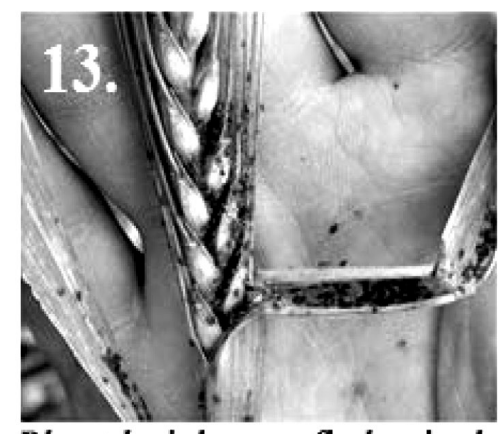

Rhopalosiphum rufiadominale

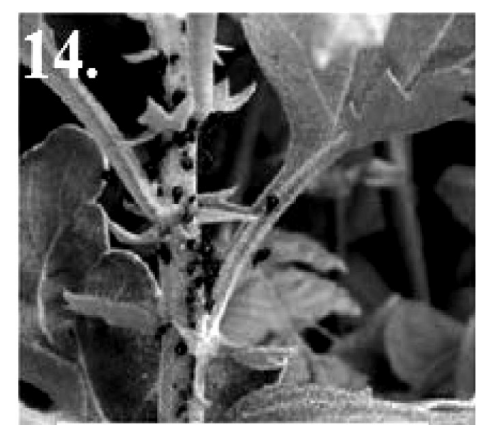

Urolencon compositae

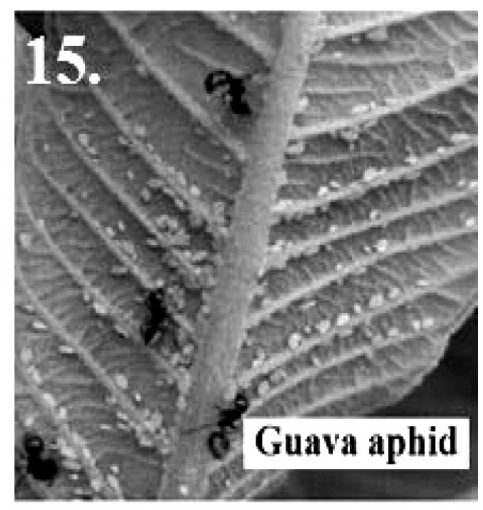

FIg. 5. Aphid species: (13.) Rhopalosiphum rufiadominale, (14.) Uroleucon compositae, (15.) Guava aphid.

Fifteen aphid species infesting crops, vegetables, and ornamental and wild plant species were reported for the first time from Kanchanpur district, Nepal. The aphids encountered during the study were cosmopolitan with no solitary endemic species. The recorded aphid species with these plants suggests that these species have adapted to most of these plants as their regular reservoir hosts to tend over the period. However, these economically beneficial plants are suffering from both the quantitative and qualitative losses associated with aphid infestation. Cottier (1953), mentioned six species of aphids from Nepal for the first time. However, Thapa (2015) reported more than 199 species of aphids under 89 genera from Nepal, but aphid reports from the western region are still lacking. The aphid species reported by him are similar to the ones recorded in the present study. In addition, at least 194 species of poaceae family are found to be infested by 139 aphid species in India (Singh et al., 2015).

Aphis craccivora is found to be the dominant and widely distributed aphid species in the present study, followed by L. erysmi and A. gossypi. Higher incidence of A. craccivora may be due to its polyphagous nature. Tamrakar (2001) reported that at least twenty 
eight plant species got infested by $A$. craccivora suggesting its polyphaous nature. Aphis craccivora is generally found abundant in all the seasons, however other aphid species show their abundance during certain specific seasons. The least abundant aphid species found in this study was $A$. nerii, which may possibly be due to its limited host range.

Findings of the present study may therefore provide the preliminary baseline data for the future workers to further explore the aphid-host plants associations, especially of the farwestern region of Nepal. Moreover, the prestnt study may help the agriculturalists and IPM managers to opt for the appropriate control strategies for protecting the food crops and/or propagating or conserving the economically important plant species in the study area.

\section{ACKNOWLEGDEMENTS}

The author is thankful to Campus Chief, Siddhanath Science Campus (T. U.), for providing laboratory facilities to conduct the study and also thankful Dr. Bhupendra Kumar, BHU, India for the identification of Aphids.

\section{REFRENCES}

BLACKMAN, R L; EASTOP, V F (1994) Aphids on the world's trees an identification and information guide. CAB International in association with the Natural History Museum Wallingford, United Kingdom; 1024 pp.

BLACKMAN, R L; EASTOP, V F (2000) Aphids on the world's crops: an identification and information guide. John Wiley \& Sons, Chichester, UK; 475 pp.( $2^{\text {nd }}$ edition).

BLACKMAN, R L; EASTOP, V F (2012)Aphids on the world's plants: An online identification and information guide. Available at: http://www.aphidsonworldsplants.info.

COTTIER, W (1953) Aphids of New Zealand. New Zealand DSIR bulletin 106.

DE ZOETEN, G A; SKAF, J S (2001) Pea enation mosaic virus and the vagaries of a plant virus. Advances in Virus Research 57: 323 - 350.

DIXON, A F G (1998) Aphid Ecology: an optimization approach. Chapman \& Hall., London, New York; 300pp. (2 $2^{\text {nd }}$ edition).

HAMMAN, P J (1985) Aphids on trees and shrubs. L-1227. Texas Agricultural Extension Service House and Landscape Pests. College Station, Texas, USA; p 2. 
106 Bista: Diversity of aphid pests on the crops in Kanchanpur district, Nepal

disease management. CSIRO Entomology Farming Ahead, p174.

HULL, R (1981) Pea enation mosaic virus. Handbook of plant virus infections and comparative diagnosis In KURSTAK, E. (ed ). Elsevier/North-Holland Biomedical Press, Amsterdam, Netherlands; pp239 - 256.

KATIS, N I; TSITSIPIS, J A; LYKOURESSIS, D P; PAPAPANAYOTOU, A; KOKINIS, G M; PERDIKIS, D C; MANOUSSOPOULOS, I N (2006) Transmission of Zucchini yellow mosaic virus by colonizing and non-colonizing aphids in Greece \& new aphid vectors of the virus. Journal of Phytopathology 154: 293-302.

LUCKMAN, W H; METCALF, R L (1978) The pest management concept. In: Introduction to Insect Pest Management. John Willey \& Sons, New York, USA; pp 3-35.

MISRA, S D; KURL, S P (1979) The life of aphids. Science Reporter 16: 608-613.

ONSTAD, D W (2008) Insecticide resistance management: biology, economics and prediction. Academic Press, London, UK; 320pp.

SHARMA, K C (2000) Aphids of Nepal. Sajha Prakashan Pulchowk, Lalitpur, Nepal.

SILVA, A X; BACIGALUPE, L D; LUNA-RUDLOFF, M FigueroA, C C (2012). Insecticide resistance mechanisms in the green peach aphid Myzus persicae (Hemiptera: Aphididae) II: Costs and benefits. PlosOne 7: e36810. doi:10.1371/ journal.pone.0036810. doi: 10.1371.

SINGH. R; SINGH, G; AGRAWAL, R; TIWARI, A K; PATEL, S; SHARMA, A; SINGH, B B (2015) Host plant diversity of aphids (Homoptera: Aphididae) infesting cereals and grasses (Poaceae) in India. International Journal of Zoological Investigations 1 (2): 91-117.

THAPA, V K (2015) Insect diversity in Nepal. Format Printing Press, Kathmandu,Nepal; $1196 \mathrm{pp}$.

TAMRAKAR, A S (2001) Incidence and distribution of Aphis craccivora Koch on various Host plants in mid-hill and terai of Nepal. Nepal Journal of Science and Technology 3: 47-50.

WHALON, M E; MOTA-SANCHEZ, D; HOLLINGWORTH, R M (2008) Global pesticide resistance in arthropods. Oxford University Press,UK; 169pp. 